\title{
Prevalence of Vitamin D Deficiency among Adult Patients in A Tertiary Care Hospital
}

\author{
Chandra Kala Rai, ${ }^{1}$ Biju Shrestha, ${ }^{1}$ Jyotshna Sapkota, ${ }^{2}$ Jay Kumar Das ${ }^{3}$ \\ 'Department of Physiology, Kathmandu Medical College, Duwakot, Bhaktapur, Nepal, ${ }^{2}$ Department of Microbiology, \\ Kathmandu Medical College, Duwakot, Bhaktapur, Nepal, ${ }^{3}$ Department of Pathology, Kathmandu Medical College and \\ Teaching Hospital, Sinamangal, Kathmandu, Nepal.
}

\section{ABSTRACT}

Introduction: The deficiency of vitamin D is major public health problem worldwide. It is deficiency of vitamin D level when blood serum which is below $30 \mathrm{ng} / \mathrm{ml}$. The deficiency is associated with various musculoskeletal diseases and autoimmune diseases. The early detection of deficiency plays important role to prevent those diseases. The aim of the study is to find the prevalence of vitamin D deficiency among adult population in a tertiary care hospital.

Methods: This descriptive cross-sectional study was conducted in tertiary care hospital, from $1^{\text {st }}$ August 2017 to 31 $1^{\text {st }}$ December 2018 after ethical clearance from institutional review committee with registration number 02082017. Simple random sampling was done. Data was collected and entered in statistical package for social sciences. Point estimate at 95\% Confidence Interval was calculated along with frequency and proportion for binary data.

Results: Out of total patients, vitamin D deficiency was found among 283 (73.6\%) patients at 95\% of CI (68.6-78.6). Out of total female patients, 202 (52.61\%) were deficient and out of total male patients, $81(21.08 \%)$ were deficient. The mean age \pm SD of patients was $41.45 \pm 16.016$ years.

Conclusions: The prevalence of vitamin D deficiency was high compared to previous studies. Vitamin D deficiency was found to be higher in females than males.

Keywords: prevalence; vitamin D; vitamin D deficiency.

\section{INTRODUCTION}

Vitamin D deficiency is recognized as a major public health problem in the world. Vitamin D maintains calcium homeostasis of bone. Low concentrations of vitamin D lead to alterations in calcium and phosphorous homeostasis and results osteoporosis. ${ }^{1}$ The deficiency is due to inadequate exposure to the sun and lack of vitamin D rich diet. It is associated with risk of autoimmune diseases, hypertension, and infectious diseases. ${ }^{2}$ Inadequate/insufficient vitamin $D$ is $<75 \mathrm{nmol} / \mathrm{l}$ (30 ng/ $\mathrm{mL})$. $^{3}$

Various studies in vitamin $D$ deficiency showed the rate of prevalence is up to $50-90 \%$ in both tropical and sub- tropical population. ${ }^{4}$ Increased deficiency level is the major indicator for metabolic syndrome, cardiovascular disease (CVD), musculoskeletal disorder and osteoporosis. ${ }^{5}$ Early finding of vitamin $D$ deficiency and supplement can decrease the risk of many diseases and mortality rate. ${ }^{6}$

The main objective of this study was to find out prevalence of vitamin D deficiency in adults patient in Kathmandu Medical College and Teaching Hospital.

Correspondence: Dr. Chandra Kala Rai, Department of Physiology, Kathmandu Medical College, Duwakot, Bhaktapur, Nepal. Email: drchandrak79@gmail.com, Phone: +977-9841380032. 


\section{METHODS}

This is a descriptive cross-sectional study which was performed among OPD patients in Department of Pathology, Kathmandu Medical College and Teaching Hospital, Sinamangal, Kathmandu, Nepal from $1^{\text {st }}$ August 2017 to $31^{\text {st }}$ December 2018. The ethical approval was received from Institutional Review Committee of Kathmandu Medical College and Teaching Hospital (Ref:02082017). Study population of this study are all the OPD patients of age group 15 to 75 years were included. Patients above 75 years and below 15 years, chronic disease and malignancy were excluded.

Level of vitamin $D$ is tested by quantitative method, chemiluminescent immunoassay (CLIA) methods. Blood sample $(5 \mathrm{~mL})$ was taken in gel tube for each subject and serum was separated by centrifuge to estimate vitamin D [25(OH)D]. Vitamin D estimation was performed in the pathology lab by chemiluminescent immunoassay (CLIA). The value less than $30 \mathrm{ng} / \mathrm{ml}$ was considered as deficient and above it was considered non-deficient.

Simple random sampling was done and sample size was calculated using the following formula,

$\mathrm{n}=\mathrm{Z}^{2} \times \mathrm{pq} / \mathrm{e}^{2}$

Where, $\mathrm{n}=$ sample size

$Z=1.96$ for $95 \%$ Confidence interval

$\mathrm{p}=$ prevalence, $50 \%$

$\mathrm{q}=1-\mathrm{p}$

$\mathrm{e}=$ margin of error $=5 \%$

Based on the above formula, the minimum samples size was 384 and further subgroup analysis was done on the basis of age and gender.

Selection and information bias has been minimized as possible. Data was analyzed by using Statistical Package of Social Science (SPSS) software version 16, point estimate at $95 \% \mathrm{Cl}$ was calculated along with frequency and proportion for binary data.

\section{RESULTS}

Out of total 384 patients, vitamin D deficiency was found among $283(73.6 \%)$ patients at $95 \% \mathrm{Cl}$ (68.678.6) (Figure 1). Out of total female patients, 202 $(52.61 \%)$ were deficient and out of total male patients $81(21.08 \%)$ were deficient (Table 1$)$. Mean age \pm SD of patients age from 15-75 years, was estimated to be $40.45 \pm 16.016$ years. Total of 384 patients were included [Male: 108 (28.09\%) and Female: 276 $(71.89 \%)]$ from OPD of Kathmandu Medical College and Teaching Hospital, Sinamangal.

\begin{tabular}{|lrlr|}
\hline \multicolumn{4}{|l|}{$\begin{array}{l}\text { Table 1. Prevalence of Vitamin D deficiency in } \\
\text { different gender. }\end{array}$} \\
\hline Gender & $\begin{array}{l}\text { Vitamin } \\
\text { Deficient } n \\
(\%)\end{array}$ & $\begin{array}{l}\text { Vitamin Non- } \\
\text { Deficient } n \\
(\%)\end{array}$ & Total $\mathrm{n}(\%)$ \\
& 202 & & \\
Female & $(52.61)$ & $74(19.28)$ & $276(71.89)$ \\
Male & $81(21.08)$ & $27(7.01)$ & $108(28.09)$ \\
Total & $283(73.3)$ & $101(26.3)$ & $384(100)$ \\
\hline
\end{tabular}

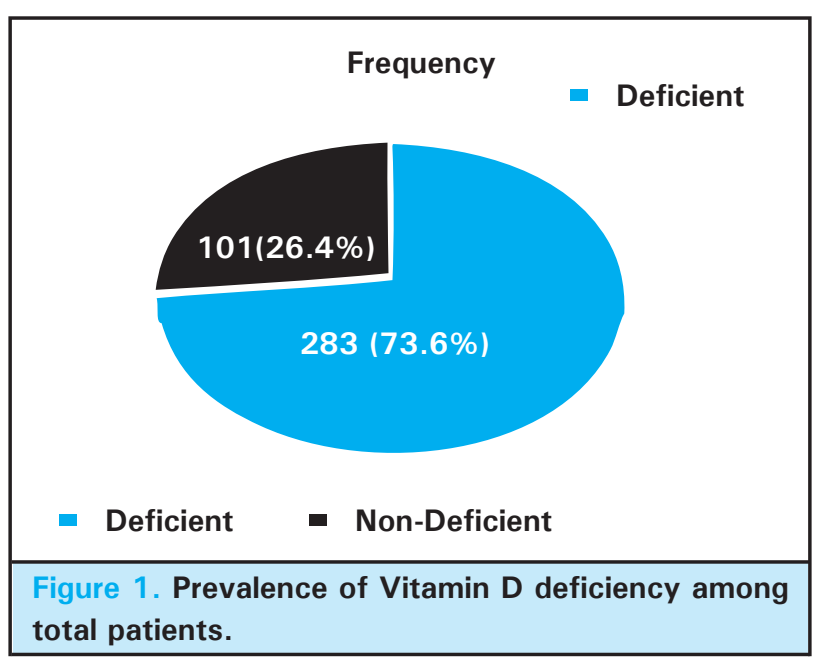

DISCUSSION

In our findings, the prevalence of vitamin $D$ deficiency were found to be similar by Kurt A. Kennel 73\%.7 A study done by Forrest $\mathrm{KY}$ showed prevalence of $41.65 \%$ in US adults. Maximum $82.1 \%$ deficiency was seen black population. ${ }^{8}$ A study done in Beijing by Ning Z.et.al showed the prevalence of deficiency by $87.1 \% .^{8}$ A study in France showed $92.3 \%$ of participants were deficient of vitamin D. ${ }^{9}$

Similar to this study, a study done in Beijing showed the higher rate of prevalence in female $89.0 \%$ and male was $84.9 \% .{ }^{10}$ A study of Saudi Arabia showed prevalence of male deficient was $87.8 \% .{ }^{11}$ A study of Northern Vietnam showed the prevalence of vitamin D deficiency in women was $30 \%$, almost two-fold higher than in men $(16 \%) .^{12}$

The limitation of the study was carried out on only one hospital and thus cannot be generalized. The research would be more effective if the personal history of sun exposure and dietary habit were included. 
Rai et al. Prevalence of Vitamin D Deficiency among Adult Patients in a Tertiary Care Hospital

\section{CONCLUSIONS}

Prevalence of Vitamin D deficiency is higher compared to previous studies. The prevalence of Vitamin D deficiency is higher in females than males. If the deficiency can be detected early, prompt management can be carried out and thus complications can be prevented.

Conflict of Interest: None.

\section{REFERENCES}

1. Bhatta MP, Pandey BR, Gurung KM, Nakarmi R, Kshamata G, Gurung LB, et al. Prevalence of vitamin D deficiency among adult population of Western Region of Nepal. Int J Med Biomed Sci. 2016;1(2):7-12. [Full Text]

2. Holick MF, Chen TC. Vitamin D deficiency: a worldwide problem with health consequences. Am J Clin Nutr. 2008;87(4):1080S-6S. [uuMed | Full Text | DOI]

3. Ross $\mathrm{AC}$, Taylor $\mathrm{CL}$, Yaktine $\mathrm{AL}$, and Valle $\mathrm{H}$. Institute of Medicine. Dietary Reference Intakes for Calcium and Vitamin D. Washington, DC: The National Academy Press; 2011. [Full Text]

4. Shah P, Kulkarni S, Narayani S, et al. Prevalence Study of Vitamin D Deficiency and to Evaluate the Efficacy of Vitamin D3 Granules 60,000 IU Supplementation in Vitamin D Deficient Apparently Healthy Adults. Internal Medicine Indian Journal of Clinical Practice. 2013 May;23(12):827-32. [Full Text]

5. Cigolini M, Pina Iagulli MP, Miconi V, Galiotto M, Lombardi S, Targher G. Serum 25-Hydroxyvitamin D3 Concentrations and Prevalence of Cardiovascular Disease Among Type 2 Diabetic Patients. Diabetes Care. 2006 Mar; 29(3): 722-4. [Full Text | DOI]

6. Martucci G, McNally D, Parekh D, Zajic P, et al. Trying to identify who may benefit most from future vitamin D intervention trials: a post hoc analysis from the VITDAL-ICU study excluding the early deaths. Crit Care. 2019 Jun 4;23(1):200. [PubMed | Full Text | DOI]
7. Kennel KA, Drake MT, Hurley DL. Vitamin D Deficiency in Adults: When to Test and How to Treat. Mayo Clin Proc. 2010 Aug;85(8):752-8. [라Med | Full Text | DOI]

8. Forrest KY, Stuhldreher WL. Prevalence and correlates of vitamin D deficiency in US adults. Nutr Res. 2011 Jan;31(1):48-54. [PubMed | Full Text | DOI]

9. Ning Z, Song S, Miao L, Zhang $\mathrm{P}$, et al. High prevalence of vitamin D deficiency in urban health checkup population. Clin Nutr. 2016 Aug;35(4):859-63. [PubMed | Full Text | DOI]

10. Deplanque X, Wullens A, Norberciak L. Prevalence and risk factors of vitamin $\mathrm{D}$ deficiency in healthy adults aged 18-65 years in northern France. Rev Med Interne. 2017 Jun;38(6):368-73. [PubMed | Full Text | DOI]

11. Ardawi MS, Sibiany AM, Bakhsh TM, Qari MH, Maimani AA. High prevalence of vitamin D deficiency among healthy Saudi Arabian men: relationship to bone mineral density, parathyroid hormone, bone turnover markers, and lifestyle factors. Osteoporos Int. 2012 Feb;23(2):675-86. [PubMed । Full Text]

12. Nguyen HT, von SB, Nguyen TV, Dzung DN, Duc PT, Thuy VT, Hirschberg AL. Vitamin D deficiency in northern Vietnam: prevalence, risk factors and associations with bone mineral density. Bone. 2012 Dec;51(6):1029-34. [PubMed | Full Text | DOI]

This work is licensed under a Creative Commons Attribution 4.0 International License. The images or other third party material in this article are included in the article's Creative Commons license, unless indicated otherwise in the credit line; if the material is not included under the Creative Commons license, users will need to obtain permission from the license holder to reproduce the material. To view a copy of this license, visit http://creativecommons.org/licenses/by/4.0/ 